\title{
Corruption and Economic Growth: The Case of EMCCA
}

\author{
Assoumou Ondo \\ CIREGED, Omar Bongo University, Libreville, Gabon \\ Email: assoumou7ondo@gmail.com
}

How to cite this paper: Ondo, A. (2017) Corruption and Economic Growth: The Case of EMCCA. Theoretical Economics Letters, 7, 1292-1305.

https://doi.org/10.4236/tel.2017.75088

Received: June 5, 2017

Accepted: July 30, 2017

Published: August 2, 2017

Copyright $\odot 2017$ by author and Scientific Research Publishing Inc. This work is licensed under the Creative Commons Attribution International License (CC BY 4.0).

http://creativecommons.org/licenses/by/4.0/

\begin{abstract}
This article analyzes the relationship between corruption and economic growth in the countries of the Economic and Monetary Community of Central Africa (EMCCA). To our knowledge, there are no works dealing with the direct relations between the two variables in such a framework. For this purpose, we use panel data econometrics to show that over the period 2005 to 2015, corruption has favored economic growth in the CEMAC member countries by "grazing" the administrative burdens that impede access basic public services (water, electricity, public hospitals and public schools), the creation and development of private enterprises.
\end{abstract}

\section{Keywords}

Corruption, Endogenous Growth, Static Panel

\section{Introduction}

Despite the important role of the state in promoting economic growth [1], increasing public spending is not necessarily desirable in a context of corruption, as growth can be degraded [2] [3] [4] [5].

The theoretical literature on the relationship between corruption and economic growth reveals three (3) main points of view. The first, defended by Shleifer and Vishny (1993) [6], Mauro (1995 and 1998) [2] [4]; Tanzi (1998) [7] and Svensson (2005) [8] supported the public choice theories [9] [10] [11] to support the hypothesis that corruption acts as "sand in the wheel" the growth. It creates dysfunctions in the public sector (the inefficiency of the legal system, bureaucratic inefficiency and political instability) that hamper economic growth by three main channels: the private investment channel [2], human capital [12] and the channel of trade openness [13]. The second point of view, developed by Leff (1964) [14], Leys (1965) [15], Huntington (1968) [16], on the contrary, 
considers corruption to be a "much needed fat for the squeaking of wheels of a rigid administration"; It can be used to "oil the wheels" of growth. Corruption would be a "second-tier solution", which would be a competitive auction game, which reproduces the efficiency of the competitive market in the presence of incomplete information [14] [17] [18]. The third point of view, initiated by Ventelou (2002) [19]; Mauro (2004) [5]; Méndez and Sepúlveda (2006) [20]; Aidt et al. (2007) [21]; Meon and Weill (2010) [18] propose an analysis in terms of multiple equilibrium which suggests a nonlinear relation between the two (2) variables. This non-linearity permits the existence of two (2) types of equilibria, a "high" equilibrium (high growth, political stability, low corruption) and a "low" equilibrium (the contrary ...), determined according to the quality of the framework Institutional, type of political regime, etc.

On the empirical level, several studies attempt to determine the effect of corruption on growth. In developed countries, Mauro (1997) [3] shows that corruption has negative effects on gross domestic product (GDP) and growth. Specifically, it analyzes 94 countries and shows that a $2.38 \%$ reduction in corruption would increase annual GDP per capita growth by $0.5 \%$. Pelligrini and Gerlagh (2004) [13] analyze the relationship between corruption and growth through linear regressions. They find that the harmful effect of corruption on growth is up to $81 \%$ through indirect effects. In the transmission of this impact, investment would be the largest channel (32\%), followed by trade opening (28\%). By integrating the case of developing countries, Campos et al. (2010) study 460 estimates (from 41 different empirical studies) dealing with the relationships between corruption and economic growth. They report that $32 \%$ of the estimates indicate a significant and negative effect of corruption on economic growth, $62 \%$ suggest that the relationship would be rather insignificant, while $6 \%$ support the hypothesis that corruption undermines the mechanisms of growth economic. More recently, Mallik and Saha (2016) [22] study the growth-corruption relationship in a sample of 146 (developed and developing countries) for the period 1984 to 2009. They estimate a polynomial regression with economic and institutional factors, which shows that corruption does not systematically have a negative effect on economic growth. In the case of African countries, BaliamouneLutz and Ndikumana (2008) [23] study a panel of 33 African countries in the Sahara south in the period 1982-2001 and show that corruption influences economic growth through investment. In a similar study Haydaroğlu (2016) [24] discusses the relationship between corruption, economic freedom and growth in the period 1996-2014. It shows that a shock on corruption has a negative impact on the economic growth of sub-Saharan African countries characterized by poor governance.

However, despite the large volume of empirical work dealing with the influences of corruption on economic growth, there are, to our knowledge, no studies of particular interest to the countries of the Economic and Monetary Community of Central Africa (EMCCA). Yet, the study of the relationship between corruption and growth is acute in such a framework for at least three reasons: 
1) First, according to NGOs Transparency International (TI) and Freedom House, EMCCA countries would be characterized by relatively low values of the Corruption Perceptions Index (CPI), which overall situates them in the Endemic corruption, and high values of the Global Civil Liberty Index (GCLI), a feature of a state where citizens live in fear and repression [25];

2) Secondly, the public administrations of the countries of the union are, for the most part, characterized by cumbersome and excessive regulation. This increases the informality, hinders the creation and development of enterprises [26] [27];

3) Thirdly, according to the Monetary Policy Committee (MPC) of the Bank of Central African States (BCAE), the growth rate of EMCCA was almost zero in 2016. It set $0.2 \%$ in 2016 , compared with $1.6 \%$ in 2015 and $4.9 \%$ in 2014 , due to the unfavorable performance in the oil sector and the reduction of public investment.

This paper proposes to enrich the existing literature in which it seems to be the first study to deal with the direct effect of corruption on the growth of the EMCCA countries while explicitly integrating civil liberty as an institutional variable of control. The rest of the study is structured as follows: Section 2 presents the review of the literature. Section 3 presents the model for determining the direct effect of corruption on economic growth. Section 4 provides an empirical analysis of panel data in order to take into account the specific effects in each member country of the union. Finally, Section 5 concludes.

\section{Literature Review}

The literature on the relationship between corruption and economic growth is abundant and focuses on three main approaches.

\subsection{First Approach: Sand in the Wheel}

The first approach assumes that corruption acts as "sand in the wheel". This approach considers corruption to lead to theft and embezzlement by public officials, leading to a net capital loss [28]. As a result of this institutionalized corruption, governments direct tax revenues to non-productive sectors where bribes are very abundant. As a result, government spending on productive projects, such as public education and health care provision, may decline as they offer fewer possibilities for rent seeking for public servants [6] [13] [29] [30]. This point of view is supported by several empirical studies.

Indeed, in his seminal work, Mauro (1995) [2] points to the negative relationships between corruption and the rate of investment and, on the other hand, between corruption and the rate of growth, 67 countries in the period 19601985. The author asserts that corruption contains growth by reducing private investment. Specifically, it finds that "an increase in one standard deviation of the corruption index is associated with an increase in the rate of investment of $2.9 \%$ of the Gross Domestic Product". Such a result is no different when small or great corruption is regressed. 
In another study, Mauro (1996) [31] shows that an improvement of a standard deviation of the corruption index allows a $4.2 \%$ increase in the investment rate and a $0.6 \%$ increase in the Gross National Product (GNP) per capita. The author also shows that corruption alters the composition of public spending to the detriment of expenditure on education and health, as corruption affects the structure of these expenditures in favor of programs facilitating the taking of bribes, (For example, in large international transactions, the purchase of hightech "custom-made" equipment is preferred because the absence of market prices limits comparative controls). The analysis also shows that it is through private investment that corruption reduces growth. This impact represents at least a third of its overall negative impact.

Mauro (1997) [3] is still analyzing the relationships between corruption and growth, but this time from 94 countries, and suggests that a reduction in corruption by 2.38 points (from its 10-point scale) would increase a country's investment by $4 \%$ of GDP and would increase per capita GDP growth by $0.5 \%$. However, political stability could have a more significant effect on economic growth compared to bureaucratic inefficiency. In addition, Mauro (1998) [4] assesses how predatory officials can distort the composition of public spending by reducing education expenditures as they do not promote rent capture.

Ehrlich and Lui (1999) [30] are also interested in the channels of transmission of corruption to growth. They are mostly focused on the human capital channel and show that corruption distances resources from education investments to political capital investments or power-seeking activities, thus jeopardizing longterm growth.

In a recent study, Pelligrini and Gerlagh (2004) [13] analyze the relationships between corruption and economic growth via linear regressions. They reach the same conclusion as Mauro (1995) [2]. According to these authors, the harmful effect of corruption on economic growth is $81 \%$ through indirect effects. They are also interested in the channels of transmission of corruption on economic growth and the results obtained suggest that investment would be the most important channel with a contribution of $32 \%$.

Méon and Sekkat (2005) [17] examine the impact of corruption on growth, taking into account the interactions between institutional quality and corruption. The results suggest that a weak rule of law, political violence and ineffective government would aggravate the negative impact of corruption on investment and that corruption slows growth in countries suffering from inefficient government, A weak state of law. The study concludes that not only does corruption impact growth through reduced capital accumulation, but also through other channels. This study shows that by reducing the level of corruption, GDP growth would increase, although other aspects of governance remain poor.

Baliamoune-Lutz and Ndikumana (2009) [24] study the effects of corruption on public and private investment in a sample of 33 African countries during the period 1982-2001. The empirical evidence indicates that corruption directly affects economic growth, and also transits through investment channels. More 
specifically, they show that corruption has a positive effect on public and negative investment on private investment. The authors therefore corroborate the view that corruption hampers economic growth and calls for institutional reforms to improve the quality of governance as a prerequisite for investment-led economic growth.

Again in the African context, Ouattara (2011) [32] analyzes the impact of corruption on public and private investment in Côte d'Ivoire and their effects on GDP growth. Using data from the World Development Indicators (WDI) and Transparency International (TI) over the period 1998-2009, it shows empirically that corruption is an overestimating factor in investment in Côte d'Ivoire and these have perverse effects on GDP growth. On this basis, the author recommends a greater awareness of the political and economic actors to the harms of corruption. It also suggests the establishment of a national authority with an exceptional sanctioning power to better combat corruption in all its forms.

Omrane (2016) [33] studies the influence of corruption on economic growth in Algeria during the period 1995-2012, using an endogenous growth model augmented by corruption. It estimates the OLS model and shows a significant and negative relationship between corruption and investment on the one hand and corruption and public spending on the other and an effect The negative impact of corruption on economic growth.

\subsection{Second Approach: Grease in the Wheel}

Unlike previous studies, several studies [14] [16] argue that corruption can have positive effects. According to this approach, corruption would act as a "fat needed for the squeaking of wheels of a rigid administration"; It can be used to "oil the wheels" of economic growth in a context where regulation is omnipresent and cumbersome (weak governance). Bureaucratic corruption is seen as a second-best solution that can effectively reduce the burden of excessive regulation and therefore have positive effects on growth [27]. In other words, in a context of imperfect competition where several market failures prevail due to weak governance measures, corruption can induce positive change by distorting the distorted market, thus bringing dynamic and allocative efficiency [34]. Proponents of this theory of "functionalism" argue that corruption can be socially beneficial and promote GDP growth through multiple mechanisms [30] [35]. First, corruption can increase bureaucratic efficiency by reducing barriers to growth. In countries characterized by cumbersome state regulation, and demotivated bureaucrats, corruption sometimes works as a solution to reduce bureaucracy. It would help entrepreneurs to circumvent heavy and rigid government regulations, circumvent expensive delays and reduce waiting costs [14] [15] [16] [29] [36]. Operating as in a "competitive bidding", corruption helps to improve the effectiveness of government intervention by diverting scarce public funds to the "highest bidder", since only the most efficient firms are likely to pay [14] [29] [37]. Corruption would also make it possible to choose effective investment projects when certain government expenditures prove to be ineffective 
[22]. In addition, corruption can also function as a "hedge" against bad economic policies of the state. As argued by Leff (1964) [14], corruption can help reduce the potential losses of government errors by allowing private entrepreneurs to implement policies not approved by the government. Corruption, as a rational response of the market to state failures, could rectify these state errors by preventing inefficient regulations [38]. Overall, the approach assumes that corruption is an effective instrument for rapid economic growth in poor countries, as it not only brings elasticity and humanity to rigid bureaucracies, but also strengthens the private sector public sector. Empirical studies supporting the idea that corruption has a positive linear effect of corruption on growth are few.

Indeed, Campos et al. (2010) [39] study 460 empirical estimates of the effect of corruption on economic growth from 41 different studies. They report that 32\% of the estimates report a significant and negative impact of corruption on economic growth, $62 \%$ suggests a statistically insignificant relationship, while $6 \%$ of the estimates support a positive and significant relationship between the two variables. For the authors, there is little empirical evidence to support the idea that corruption would act as a "much needed fat in the mechanics of growth". However, the authors note that most of these studies exclude indicators of institutional quality as an explanatory variable, which in light of recent research is a major gap.

In a recent study, Ghoneim and Ezzat (2015) [40] study the relationship between corruption and growth in the Arab world. They estimate a model with random effects panel data to determine the impact of corruption on economic growth in 15 Arab countries over the period 1998-2009. The results of the study show that the direct impact of corruption on GDP growth depends strongly on other variables, including the governance structure. Thus, when the latter is very poor, the impact of corruption on GDP growth tends to be positive, which goes hand in hand with the "grease wheels" hypothesis.

\subsection{Third Approach: Nonlinear Relationship}

More recently, highlighting multiple equilibria in theoretical models dealing with the relationship between corruption and GDP growth and, due to the existence of mixed empirical results, the latest work suggests that the effects between the two (2) variables could be nonlinear. This third approach seems to rehabilitate the idea that corruption is used to lubricate the wheels of growth. A number of works follow this direction.

Ventelou (2002) [19] discusses the concept of "political corruption" and attempts to establish the conditions for its integration into applied economic analysis. In a micro-economy of corruption, it shows that a law enforcement officer who optimizes a flow of embezzlement will be highly sensitive to the instability associated with his office. The macroeconomic consequences of corruption on growth are then specified; According to the stylized facts, the growth rate is affected. In fact, two (2) equilibria emerge from the politico-economic game: a "high" balance (high growth, political stability, low corruption) and a "low" 
equilibrium.

Mauro (2004) [5] identifies different equilibria depending on the time individuals spend working to the detriment of "rent seeking" activities. It shows that there is a "good" balance characterized by high prohibition and high growth; and a "bad" balance with high corruption and low economic growth. In addition, Méndez and Sepúlveda (2006) [20] also argue that the relationship between corruption and growth is non-monotonous (quadratic) and that this relationship depends on the degree of political freedom, because corruption has a positive impact on GDP growth In the long term for low levels of incidence but is detrimental to high levels and therefore there can be an optimal level of corruption that maximizes growth. Aidt, Dutta and Sena (2007) [21] also propose a model in which they study the relationship between corruption and economic growth, given the politico-institutional quality. In this model, corruption is defined as an annuity that taxpayers levy on tax revenues. Their model also admits of multiple equilibria, determined according to the level of the quality of the institutions;

Based on these models, Swaleheen (2011) [41] estimates the effects of corruption on GDP growth in a non-linear model on panel data using the Generalized Method of Momentum Method (GMMS). The study shows that corruption does not reduce GDP growth at all levels and that it can increase GDP growth significantly, even at a higher level of corruption. Such a conclusion seems to reject the Shleifer and Vishny (1993) [6] hypothesis that corruption acts as sand in the wheels of growth.

This literature shows that the effect of corruption on growth cannot be explained without taking into account the institutional framework of countries. For example, the decisive role of institutions in determining the effects of corruption on economic growth has recently been examined by Méon and Weill (2010) [22]. For these authors, corruption would be significantly less harmful (positive) in countries where the institutional framework is less efficient (inefficient). This finding, which seems to justify the idea that effective corruption helps to overcome existing institutional gaps, is also confirmed by Heckelman and Powell (2010) [42]. Specifically, the authors show that corruption is positively associated with economic growth in countries where economic freedom is limited, but that this positive effect would tend to decrease as economic freedom increases.

In addition, Swaleheen and Stansel (2007) [43] study the relationship between corruption and economic growth by integrating the impact of economic freedom. They use an econometric model integrating economic freedom as an explanatory variable. The results of the study lead to conclusions that seem to contradict the generally accepted view in the empirical literature that corruption is detrimental to economic growth.

Mallik and Saha (2016) [23] study the growth-corruption relationship in a sample composed of 146 countries for the period 1984-2009 using the Generalized Momentum Method (MMG). The authors estimate a hierarchical polynomial relation to evaluate the relationship after controlling for economic and 
institutional factors. The findings question some of the findings in the literature claiming a negative relationship between corruption and growth, but also provide new inferences. The results show that corruption does not always have a negative effect on growth. Indeed, for some countries it helps to increase growth, which supports the idea that corruption makes it possible to "lubricate the wheels".

The literature presented showed that corruption has different effects according to institutional frameworks. Studying corruption without taking into account the institutional variables is therefore inappropriate and leads to bad conclusions. The literature has also shown that the determination of the effects of corruption on economic growth remains a question that is still not answered concretely, whether from a theory or empirical work. Several studies show a significant negative effect of corruption on growth, but this result cannot yet be generalized.

However, it is clear that until then, the EMCCA member countries have not yet attracted the attention of economists. It would be interesting to study the relationships between corruption and growth in a context characterized by administrative cumbersomeness and excessive regulation which hamper the creation of enterprises (World Bank, 2004 and 2006). Moreover, the EMCCA countries are also evolving poorly in terms of economic growth and civil liberty compared to other regions. These two (2) stylized facts suggest the possibility that corruption acts as a "fat for the wheels" of economic growth.

\section{The Model of Determining the Direct Effect of Corruption on Economic Growth}

Like Mauro (1995) [2], Pelligrini and Gerlagh (2004) [13], we assume a model of endogenous growth, where economic growth $\left(g_{i, t}\right)$ is determined by corruption $\left(\right.$ corr $\left._{i, t}\right)$, standard variables of economic growth $\left(X_{i, t}^{1}\right)$ and institutional variables $\left(X_{i, t}^{2}\right)$.

Economic growth $\left(g_{i, t}\right)$ is the explanatory variable of the model. It is defined by the growth rate of the gross domestic product. Given the levels of corruption endemic in the majority of the EMCCA member countries, we consider a linear relationship to study the direct effect of corruption (political and subordinate agents) on economic growth. As a result, the model for determining the direct impact of corruption on economic growth is as follows:

$$
g_{i, t}=\alpha_{0}+\alpha_{1} \operatorname{corr}_{i, t}+\beta^{1} X_{i, t}^{1}+\beta^{2} X_{i, t}^{2}+\epsilon_{i, t}
$$

where:

$g_{i, t}$ is economic growth;

corr $_{i, t}$ the corruption;

$X_{i, t}^{1}$ the vector of the standard variables used by most studies on growth;

$X_{i, t}^{2}$ is the vector of institutional variables;

$\epsilon_{i, t}$ the term of error.

The economic literature identifies three main indices of measuring corruption: 
the International Country Risk Guide (ICRG); Corruption Perceptions Index (CPI) created by Transparency International (TI) and the World Bank's Corruption Control Index (CCI) [23]. Like Gyimah-Brempong and Comacho (2006) [44]; Ganuza and Hauk (2004) [45]; Mallik and Saha (2016) [23], we retain the $\mathrm{CPI}$ as a measure of corruption. Indeed, this subjective estimator, which ranks countries on a scale of 0 to 10 ( 0 indicates the most corrupt and 10 entirely clean), is the only available index for five (5) of the six (6) member countries of the EMCCA area, over the period 2005-2015. These include Cameroon, the Republic of Congo, the Central African Republic and Chad.

In our case, we consider a priori two usual determinants of growth: 1) human capital, as measured by the enrollment rate in secondary education, and 2) private investment, determined by gross fixed capital formation, 3) imports, 4) exports of goods and services, and 5) government expenditure. In addition, the trade opening rate is calculated by summing imports and exports as a percentage of GDP. As in the case of Swaleheen and Stansel (2007) [43], Heckelman and Powell (2010) [42], the institutional variable chosen in our study is 4) civil liberty, which we measure using the global index of civil liberty. This index, established by Freedom House, assesses civil liberty on a scale of 1 to 7; where the lowest scores (1 and 2) indicate that the country respects freedom of speech, assembly, freedom Religion, education, and association. The highest scores (6 and 7) are awarded to states where citizens live in strong fear and repression. Growth is ultimately determined from the equation:

$$
g_{i, t}=\alpha_{0}+\alpha_{1} \operatorname{corr}_{i, t}+\beta_{1} \operatorname{caph}_{i, t}+\beta_{2} \text { inv }_{i, t}+\beta_{3} \text { igl }_{i, t}+\beta_{4} \text { ouv }_{i, t}+\beta_{5} \text { depub }_{i, t}+\epsilon_{i, t}
$$

where:

$i$ represents the individuals of the panel and $t$, the index of time;

$g_{i, t}$ is the real GDP per capita growth rate;

corr $_{i, t}$ corruption;

$\operatorname{caph}_{i, t}$ human capital;

inv $v_{i, t}$ private investment;

iglc $_{i, t}$ civil liberty;

ouv $_{i, t}$ commercial opening;

depub $_{i, t}$ Public spending;

$\epsilon_{i, t}$ the term of the error.

The data used to enter the variables come from the World Bank database, with the exception of the corruption perception index $\left(\operatorname{corr}_{i, t}\right)$, from the NGO Transparency International (TI), and the Global Freedom Index $\left(i g c_{i, t}\right)$ which is determined by the Freedom House. Given the different orders of magnitude, human capital and private investment have been linearized by the natural logarithm operator (ln). The data collected concern five (5) CEMAC countries during the period 2005-2015.

\section{Empirical Analysis}

The estimation of Equation (2) is done by the econometrics of panel data, which has the double advantage of expanding our database on the one hand and 
analyzing the individual specificities of the countries Members of the EMCCA zone, on the other. The estimation of the static panel allows two (2) steps: the first step consists in carrying out a Fischer homogeneity test in order to verify whether we can assume that the theoretical model studied is perfectly homogeneous (the constant and The slope are the same) for all EMCCA countries, or on the contrary, if there are country-specific specificities. If the Fischer statistic, combined with the homogeneity test, is greater than the Fischer of the table, then the hypothesis of homogeneity is rejected. The second step concerns the choice of the specification of the individual effect by the Hausman test (1978) [46], and hence the estimation method. This test makes it possible to determine whether the individual effect of the model must be specified with a fixed effect or a random effect. The random effects model will be used if the probability associated with the Hausman test statistic is greater than $5 \%$. The estimates obtained will be validated by the Wald global significance test, after having tested and corrected the presence of possible autocorrelation and heteroskedasticity of the residues. The estimation of the model will be done using the Stata14 software.

The results of the Fischer homogeneity test show that the EMCCA countries are heterogeneous, confirming the existence of specificities specific to each member country of the monetary union (prob $>\mathrm{F}=0.2215$ ). Moreover, the results of the Hausman test (1978) [46] support the hypothesis that the panel has a random effect (prob $>\mathrm{khi}^{2}=0.1633$ ). The Kennedy test (1983) shows the absence of multicollinearity between the variables of the model. Moreover, the results obtained from the Breush-Pagan tests (1979 and 1980) confirm that the model is autocorrelated and heteroscedastic at the $5 \%$ threshold.

Table 1 presents the results of model estimation [2], after simultaneous correction of autocorrelation and heteroskedasticity.

The results of the Wald test show that the model is globally significant at the $5 \%$ threshold (Wald $\operatorname{chi}^{2}(6)=27.90$ and prob $>\operatorname{chi}^{2}=0.0001$ ). The coefficients obtained can therefore be used to discuss the relationship between corruption and economic growth in the CEMAC zone.

Table 1. Determinants of economic growth $\left(g_{i, t}\right)$.

\begin{tabular}{cc}
\hline Exogenous variables & Coefficients \\
\hline corruption $\left(\right.$ corr $\left._{i, t}\right)$ & $-2.9642^{* * *}$ \\
civil liberty $\left(\right.$ igl $\left._{i, t}\right)$ & $-4.002^{\star}$ \\
human capital $\left(\right.$ cah $\left._{i, t}\right)$ & -0.089 \\
private investment $\left(\right.$ inv $\left._{i, t}\right)$ & $0.373^{\star}$ \\
Commercial opening $\left(\right.$ ouv $\left._{i, t}\right)$ & 0.0607 \\
Public spending $\left(\right.$ depub $\left._{i, t}\right)$ & -0.0007 \\
Constant & $22.067^{*}$ \\
\hline
\end{tabular}

a. The determinants of growth are represented here. The Student tests on each coefficient are based on a null hypothesis of zero significance and an alternative hypothesis of non-significance at zero. When the coefficient is preceded by $\left(^{*}\right)$ then the null hypothesis is rejected at the $1 \%$ threshold; for $\left(^{* *}\right)$ the null hypothesis is rejected at the $5 \%$ threshold; For $\left.{ }^{* * *}\right)$ it is rejected at the $10 \%$ threshold. 
The results in Table 1 reveal a negative and significant relationship between the Corruption Perception Index (CPI) and growth, confirming the hypothesis of Leff (1964) [14]; Lui (1985) [36]; Méon and Sekkat (2005) [17]; Méon and Weill (2008) [18] that corruption is used to "oil the wheels" of growth. Indeed, during the period 2005-2015, corruption would have acted as a grease for the squeaking of wheels of the rigid administrations of the member countries of the EMCCA zone. The results also support the studies by Swaleheen and Stansel (2007) [43], followed by Heckelman and Powell (2010) [42], showing that an increase in corruption, corresponding to a decrease of CPI, has positive effects on the growth of Countries with low civil liberties. It would alleviate the rigidities of the public administration and would thus make it possible to circumvent the administrative delays and cumbersomeness, the excessive procedures, which discourage private investment and hinder economic growth in the union. Consequently, bribes, leg-fattening offered by private sector agents (households and businesses) to certain politicians and bureaucrats appear to be a necessary evil which would enable them to benefit from certain public services, even the most basic ones (access to water, electricity, public hospitals, public schools).

Moreover, the results show that the increase in private investment (0.3728) and the improvement of civil liberty $(-4.002)$ have positive and significant effects on the economic growth of the member countries of the CEMAC zone. This result supports the view that respect for individual freedoms (freedom of expression, freedom of assembly and religion, freedom of education, association and entrepreneurship) promotes economic growth. In terms of human capital, its impact on GDP growth is negative $(-0.089)$ but not significant. This result can be explained by the use of a very restrictive proxy for the measurement of human capital, namely: "the enrollment rate in secondary school" which does not allow an exhaustive estimation of knowledge and knowledge-to make member countries of the CEMAC. In addition, trade opening (0.0607) and public spending (0.0045) have positive and not significant effects on GDP growth in the period 2005 to 2015 . The results also show that, in view of their relatively close economic structure, the heterogeneity of GDP growth rates would be explained by random perturbations specific to each member state of the union.

\section{Conclusion}

In this article, we have studied the direct relationship between corruption and economic growth in the EMCCA member countries based on panel data econometrics in the period 2005 to 2015. More precisely, the results highlight a positive relationship between these two variables reinforces the idea that corruption acts as a "much needed fat for the squeaking of wheels of rigid administration". It would thus make it possible to circumvent administrative burdens and excessive regulations inherent in the functioning of the State in the countries of the CEMAC. However, corruption could have non-linear effects on growth. It may therefore be interesting to determine an optimal level of corruption in the countries of the CEMAC zone, taking care to distinguish channels of transmission 
from the effects of corruption on growth.

\section{Acknowledgements}

First of all, I would like to thank the editor and the referee for their comments. My thanks also go to the various members of the International Center for Reflexion in Economics and Management for Development (CIREGED) for the day-to-day discussions. Nonetheless, I am solely responsible for any errors and omissions in this study.

\section{References}

[1] Barro, R.-J. (1990) Government Spending in a Simple Model of Endogenous Growth. Journal of Political Economy, 98, 103-126. https://doi.org/10.1086/261726

[2] Mauro, P. (1995) Corruption and Growth. Quarterly Journal of Economics, 110, 681-712. https://doi.org/10.2307/2946696

[3] Mauro, P. (1997) The Effects of Corruption in Investment and Government Expenditure: A Cross-Country Analysis. In: Elliot, K.A., Ed., Corruption and the Global Economy, Institute for International Economics, Washington DC, Chapter 4.

[4] Mauro, P. (1998) Corruption and the Composition of Government Expenditure. Journal of Public Economics, 69, 263-279. https://doi.org/10.1016/S0047-2727(98)00025-5

[5] Mauro, P. (2004) The Persistence of Corruption and Slow Economic Growth. IMF Staff Papers, 5, 1-18.

[6] Shleifer, A. and Vishny, R.W. (1993) Corruption. Quarterly Journal of Economics, 108, 599-617. https://doi.org/10.2307/2118402

[7] Tanzi, V. (1998) Corruption around the World: Causes, Consequences, Scope, and Cures. International Monetary Fund Staff Papers, 45, 559-594. https://doi.org/10.2307/3867585

[8] Svensson, J. (2005) Eight Questions about Corruption. Journal of Economic Perspectives, 19, 19-42. https://doi.org/10.1257/089533005774357860

[9] Buchanan, J.-M. (1954) Individual Choice in Voting and Market. Journal of Political Economy, 62, 334-343. https://doi.org/10.1086/257538

[10] Tullock, G. (1967) Welfare Costs of Tariffs, Monopolies and Theft. Western Economic Journal, 5, 224-232. https://doi.org/10.1111/j.1465-7295.1967.tb01923.x

[11] Downs, A. (1957) An Economic Theory of Democracy. Harper \& Row, Boston.

[12] Seka, P. (2013) Corruption, Croissance et Capital Humain: Quels Rapports? Afrique et Développement, 38, 133-150.

[13] Pellegrini, L. and Gerlagh, R. (2004) Corruption's Effect on Growth and Its Transmission Channels. Kyklos, 57, 429-456. https://doi.org/10.1111/j.0023-5962.2004.00261.x

[14] Leff, N. (1964) Economic Development through Bureaucratic Corruption. The American Behavioral Scientist, 8, 8-14. https://doi.org/10.1177/000276426400800303

[15] Leys, C. (1965) What Is the Problem about Corruption? Journal of Modern African Studies, 3, 215-230. https://doi.org/10.1017/S0022278X00023636

[16] Huntington, S. (1968) Political Order in Changing Societies, Yale University Press, New Haven, Connecticut. 
[17] Méon, P.G. and Sekkat, K. (2005) Does Corruption Grease or Sand the Wheels of Growth? Public Choice, 122, 69-97. https://doi.org/10.1007/s11127-005-3988-0

[18] Méon, P.G. and Weill, L. (2010) Is Corruption an Efficient Grease? World Development, 38, 244-259. https://doi.org/10.1016/j.worlddev.2009.06.004

[19] Ventelou, B. (2002) Corruption in a Model of Growth: Political Reputation, Competition and Shocks. Public Choice, 110, 23-40. https://doi.org/10.1023/A:1013034225646

[20] Mendez, F. and Sepulveda, F. (2006) Corruption, Growth and Political Regimes: Cross Country Evidence. European Journal of Political Economy, 22, 82-98. https://doi.org/10.1016/j.ejpoleco.2005.04.005

[21] Aidt, T., Dutta, J. and Sena, V. (2008) Governance Regimes, Corruption and Growth: Theory and Evidence. Journal of Comparative Economics, 36, 195-220. https://doi.org/10.1016/j.jce.2007.11.004

[22] Mallik, G. and Saha, S. (2016) Growth and Corruption: A complex Relationship. International Journal of Development Issues, 15, 113-129. https://doi.org/10.1108/IJDI-01-2016-0001

[23] Baliamoune-Lutz, M. and Ndikumana, L. (2009) Corruption et Croissancedans les Pays Africains: le canal de l'Investissement. Economica, 17, 433-448.

[24] Haydaroğlu, C. (2016) Corruption, Institutions and Economic Growth in Sub-Saharan Africa. International Journal of Economics and Research, 7, 14-26.

[25] Transparency International (2016) Corruption Perception Index 2016. Transparency International, Berlin.

[26] Banque Mondiale (2004) World Development Report 2005. A Better Investment Climate for Everyone. Banque Mondiale, Washington DC.

[27] Banque Mondiale (2006) Résumé de l'évaluation du climat des Investissements au Cameroun. Région Afrique, département du secteur privé.

[28] Alam, M.S. (1989) Anatomy of Corruption: An Approach to the Political Economy of Underdevelopment. American Journal of Economics and Sociology, 48, 441-456. https://doi.org/10.1111/j.1536-7150.1989.tb02132.x

[29] Bardhan, P. (1997) Corruption and Development: A Review of Issues. Journal of Economic Literature, 35, 1320-1346.

[30] Ehrlich, I. and Lui, F. (1999) Bureaucratic Corruption and Endogenous Economic Growth. Journal of Political Economy, 107, 270-293. https://doi.org/10.1086/250111

[31] Mauro, P. (1996) The Effects of Corruption on Growth, Investment, and Government Expenditure, IMF Working Paper. International Monetary Fund, Washington DC.

[32] Ouattara, W. (2011) Corruption, Investissements et Croissance Économique en Côte D'ivoire. Savings and Development, 1, 55-73.

https://doi.org/10.2307/savideve.35.1.55

[33] Omrane, B. (2016) Corruption et Croissance Économique: une Approche Économétrique sur les Données de l'Algérie. European Scientific Journal, 12, $1857-$ 7431.

[34] Mironov, M. (2005) Bad Corruption, Good Corruption and Growth. University of Chicago, Chicago.

[35] Werner, S.B. (1983) The Development of Political Corruption: A Case Study of Israel. Political Studies, 31, 620-639. https://doi.org/10.1111/j.1467-9248.1983.tb01357.x

[36] Lui, F.T. (1985) An Equilibrium Queuing Model of Bribery. Journal of Political Economy, 93, 760-781. https://doi.org/10.1086/261329 
[37] Beck, P. and Maher, M. (1986) A Comparison of Bribery and Bidding in Thin Markets. Economics Letters, 20, 1-5. https://doi.org/10.1016/0165-1765(86)90068-6

[38] Jain, A.K. (2001) Corruption: A Review. Journal of Economic Surveys, 15, 71-121. https://doi.org/10.1111/1467-6419.00133

[39] Campos, N.-F., Ralitza, D. and Saleh, A. (2010) Whither Corruption? A Quantitative Survey of the Literature on Corruption and Growth, Center for Economic Policy Research, Washington DC.

[40] Ghoneim, A.F. and Ezzat, A.M. (2016) Growth and Corruption in Arab Countries: What Type of Relationship Connects Them? Journal of Economics and International Finance, 8, 44-55. https://doi.org/10.5897/JEIF2015.0675

[41] Swaleheen, M. (2011) Economic Growth with Endogenous Corruption: An Empirical Study. Public Choice, 146, 23-41. https://doi.org/10.1007/s11127-009-9581-1

[42] Heckelman, J.C. and Powell, B. (2010) Corruption and the Institutional Environment for Growth. Comparative Economic Studies, 52, 351-378. https://doi.org/10.1057/ces.2010.14

[43] Swaleheen, M. and Stansel, D. (2007) Economic Freedom, Corruption, and Growth, The Cato Journal, 27, 343-358.

[44] Gyimah-Brempong, K. and de Camacho, S.M. (2006) Corruption, Growth and Income Distribution: Are There Regional Differences? Economics of Governance, 7, 245-269. https://doi.org/10.1007/s10101-005-0008-2

[45] Ganuza, J.J. and Hauk, E. (2004) Economic Integration and Corruption. International Journal of Industrial Organization, 22, 1463-1484. https://doi.org/10.1016/j.ijindorg.2004.09.004

[46] Hausman, J.A. (1978) Specification Tests in Econometrics. Econometrica, 46, 12511271. https://doi.org/10.2307/1913827

Submit or recommend next manuscript to SCIRP and we will provide best service for you:

Accepting pre-submission inquiries through Email, Facebook, LinkedIn, Twitter, etc. A wide selection of journals (inclusive of 9 subjects, more than 200 journals)

Providing 24-hour high-quality service

User-friendly online submission system

Fair and swift peer-review system

Efficient typesetting and proofreading procedure

Display of the result of downloads and visits, as well as the number of cited articles

Maximum dissemination of your research work

Submit your manuscript at: http://papersubmission.scirp.org/

Or contact tel@scirp.org 